\title{
DOES HAVING CHILDREN REALLY MAKE A DIFFERENCE: THE CASE OF SOUTH AFRICAN FEMALE ENTREPRENEURS
}

\author{
N Meyer \\ North-West University \\ n.meyer@nwu.ac.za
}

Orcid: 0000-0003-3296-7374

Dr E Keyser

North-West University

elsabe.keyser@nwu.ac.za

Orcid no: 0000-0003-2343-0807

\section{-Abstract -}

Family responsibility has been identified as a potential unique female entrepreneur challenge. Although some females may willingly enter into entrepreneurial activity when having children as it may provide more work life flexibility, some may be challenged by time restrictions especially when children are still young. However, empirical data show that females who decide to become self-employed may in many cases do so to enjoy higher flexibility but may be restricted regarding growth and other factors such as finances, motivation and support. In light of this, the purpose of this study is to identify differences between two groups of South African female entrepreneurs: those with and those without children. Differences were compared between groups considering several factors such as, motivation, financial constraints, intention to grow the business and socio-cultural barriers to name a few. The study followed a descriptive research design using self-administered questionnaires. The questionnaires were distributed to a purposive and convenience sample of female entrepreneurs from all nine South African provinces resulting in a final sample of 510. Data were analysed using reliability and validity analysis and Multiple Analysis of Variance (MANOVA) and Analysis of Variances (ANOVA). Results indicated that the only entrepreneurial variable or factors that were influenced by having children or not were financial constraints, government support and socio-cultural barriers. Factors such as intention to remain in business, intention to grow the business and motivation returned non-statistically significant results for the said groups. The results from this study link to previous findings indicating that differences were observed between female entrepreneurs with children and those without. Further 
studies indicate that fewer differences were observed between male entrepreneurs with children and those without children, therefore implying that the presence of children among female entrepreneurs could be considered a unique challenge.

Keywords: South Africa, female entrepreneurs, challenges, children

\section{JEL Classification: L26}

\section{INTRODUCTION}

During the mid-eighteenth century, the Western industrial era brought about major global changes; however, from the onset females were excluded from mainstream economic contributions and activities. Females and males performed clearly defined and contrasting roles within society. Men were mainly involved in economic activities and public life while women were expected to be mostly homebound, taking care of cleaning, cooking and children. Nonetheless, most developing and developed countries slowly started accepting females as part of the economic sector from the late-nineteenth century onwards (Sailus, 2015:1). Recent research on the roles of females in both developed and developing countries suggest that many of them in developing nations continue to play constrained economic roles in agriculture and are restricted to participate as economic equals in these nations (Jayachandran, 2014:4; United Nations, 2008:2). Several aspects may affect female entrepreneurs in a different way compared to males or may have an impact on their business' management style and performance. Such factors include race, age, marital status and children, education, previous work experience and the presence of an entrepreneurial rolemodel. Some studies have pointed out that having children may contribute to female entrepreneurs' challenges regarding business start-up, continuation and growth (DTI, 2005; Noseleit, 2014). Based on the aforementioned, the research objective of this study is to identify differences in various entrepreneurial variables or factors between two groups of South African female entrepreneurs: those with and those without children. Understanding the magnitude of differences, if any, can contribute to policy development within female entrepreneurship development.

\section{LITERATURE REVIEW}

Entrepreneurship has been pointed out by many academics and policymakers alike as the cornerstone of economic growth and financial independence (Athayde, 2012:709-710; Sivvam, 2012:13; Ambrish, 2014:225; Kot, Meyer \& Broniszewska, 2016:207). Despite this, the potential of entrepreneurship has not 
been fully realised in many developing countries. South Africa is falling behind in terms of entrepreneurship intention and action when compared to sub-Saharan African averages and also other efficiency-driven economies; consequently, advances in this regard are necessary (Herrington, Kew \& Kew, 2015:5). Female entrepreneurs are, in particular, fewer in number than their male counterparts (Asian Development Bank, 2007; ILO, 2014:1; GEM Consortium, 2017), and reasons for this need to be identified. As mentioned, the aim of this study is to identify differences in various entrepreneurial factors between South African female entrepreneurs with and without children. The entrepreneurial factors referred to include internal and external motivation, intention to remain in and grow the business, financial constraints, government support, socio-cultural barriers and attitude towards the business. These factors are subsequently discussed in the following section.

\subsection{Entrepreneurial factors}

Motivation is the first entrepreneurial factor or variable that may potentially be influenced as a result of a female entrepreneur having children or not. Motivation, for the purpose of this study, is divided into internal and external motivation. Internal motivation includes aspects such as increased freedom, work-life balance and making a difference in society, compared to external motivations such as wealth creation and autonomy. Differences between male and female motivation for starting or remaining in business may be present. However, some studies identified similarities as well. Veena and Nagaraja (2013:140), for example, found that one of the primary reasons for self-employment for both genders is to gain more control over their working conditions. In addition, personal autonomy and self-determination were high motivational factors for both genders. However, females reported much higher motivation in an attempt to escape a confined labour market with low paying wages, strong supervisory and hierarchical structures and to discard social stereotypes (Veena \& Nagaraja, 2013:140). Along with other studies, Veena and Nagaraja (2013:140) also found that financial independence was a high motivational factor for both males and females. Nevertheless, females also listed having independence and being able to control their labour inputs as strong motivation. Similar to other findings, Veena and Nagaraja (2013:140) found that flexibility is a major motivational factor for many females deciding to start entrepreneurial ventures. This is not the case for male entrepreneurs. According to Veena and Nagaraja (2013:141) many female entrepreneurs may be more driven by internal motivations, such as increased freedom, work-life balance and making a difference in society, compared to 
external motivations such as wealth creation and autonomy (Veena \& Nagaraja, 2013:141; Kim \& Sherraden, 2014:50).

Further entrepreneurial factors that may be influenced by the presence of children among female entrepreneurs include their intention to remain in business, grow the business and their attitude towards the business. These three factors are very much linked to one another. Knight and Leimer (2010:111) mention that several factors may directly or indirectly contribute to an individual's intention to remain or leave employment. These include, but are not limited to gender, education, personal traits and interests, motivation, support, promotional opportunity and so forth. Likewise, many of these factors may also have an impact on the entrepreneur's intention to remain in business. Morrison (1997:45), in a study conducted on franchise owners, found that job satisfaction positively influences the decision to remain in business. Considering the factors mentioned by Knight and Leimer (2010:111), factors linking to support, such as government support, access to finance and socio-cultural support may have a direct or indirect impact on a female entrepreneur's intention to remain in business. When some of these factors negatively affect the entrepreneur, such as lack of finance, stereotyping, lack of government support and even lack of motivation, the appetite of the entrepreneur (job satisfaction) towards the business may be reduced, which could decrease the intention to remain in business. In addition, Knight and Leimer (2010:111) state that in cases where negative factors influence the employee (entrepreneur), females are more inclined to quit or exit the specific job situation or decide to close the business.

Additionally, Kim and Hunter (1993) found that attitude is a strong predictor of behaviour, especially goal-orientated behaviour $(\mathrm{r}=0.79)$. However, attitude may also change quite suddenly due to interactions with the direct environment and could be less stable over time (Wiklund, Davidsson \& Delmar, 2003:149). Delmar and Wiklund (2008:437) further opine that business growth is strongly linked to motivation, especially external motivational aspects; as a result, a further link could be made between motivation, attitude and growth. Motivation affects the choice of behaviour so that when a positive attitude towards the business and business growth are experienced by the entrepreneur, they may be more inclined to external motivational factors for the choice of remaining in business. This assumption is based on Ajzen's (1991) Theory of Planned Behaviour. When considering attitude as a factor of firm growth, it should be noted that growth aspirations may not be instantaneous and may only develop over time. Walker and Brown (2004:579) mention that as businesses mature, the owners may alter their 
attitudes towards business growth in a positive manner. In addition, Delmar and Wiklund (2008:438) state that this process of motivation towards achieving business growth may take up to 5 years for a small business entrepreneur to actively seek and for a positive attitude towards growth to be developed. Although the aforementioned referred to attitude towards growth, this is closely linked to the entrepreneur's attitude towards the business in general. If the entrepreneur has a strong feeling of commitment, satisfaction, passion and attachment to the business, they may even develop a more positive attitude towards growth, or it may even evolve over time.

The aforementioned factors were more positive-oriented in nature, likewise, several negative factors may also be influenced in a certain manner considering the presence of children among female entrepreneurs. These include financial constraints, lack of government support and socio-cultural barriers. Access to finance and credit for small, medium entrepresis (SMEs) is in many cases a challenge, and for female entrepreneurs, this issue is sometimes even greater (Buttner \& Rosen, 1988:250; Gicheva \& Link, 2015:729). Verheul and Thurik (2001:330) state that female entrepreneurs encounter several challenges concerning the financial aspects of their businesses. These include aspects pertaining to start-up capital and operational capital. These difficulties comprise having smaller equity capital at their disposal, sector related capital restrictions due to many female entrepreneurs operating service industry-related businesses and lending institutions being more reluctant to lend money to entrepreneurs in these sectors. Furthermore, females are, in many instances, likely to be more riskaverse than males, which may lead to their declining higher risk opportunities and lessening subsequent access to finance. In addition, female-owned businesses tend to be smaller in size and less efficient, which may result in more failed loan applications (Makina, Fanta, Mutsonziwa, Khumalo, \& Maposa, 2015:3). When considering government support, South Africa has a lengthy history regarding gender policy restrictions. Black and coloured females were deprived of taking part in any business activity pre-1994 (SAHO, 2011:1; Bobby-Evans, 2015). These political policies and lack of government support prevented many females from starting businesses and thinking entrepreneurially. However, initiatives were implemented post-1994 to redress the gender discrimination caused during the Apartheid era (SAHO, 1994:1). Despite these initiatives, there is still much necessary work to be done to level the playing field when it comes to gender representation in the economic business world and entrepreneurship development, and policy formation could assist in this (Herrington, Kew \& Kew, 2010:41). 
Finally, many socio-cultural aspects also affect female entrepreneurs more than their male counterparts: some of these include, lack of respect from the community, stereotypical treatment, doubt about their ability to conduct business, discrimination in the labour market and other workplaces, and balancing work and home duties especially when raising children. As entrepreneurship has in the past, and even to a certain extent today, been defined as a masculine and male dominated career option and females have been classified as homemakers and being responsible for raising children, a clearly stereotypical situation has emerged (Onyishi \& Agbo, 2010:3049). Maziku, Majenga and Mashenene (2014:51) mention that many females, especially in developing rural areas, are negatively affected by these socio-cultural and stereotypical aspects and that this may have an effect on the business size, growth potential and eventually, the business success rate.

\subsection{Female entrepreneurs and children}

The Department of Trade and Industry (DTI) (2005:8) identified family responsibility as a potential unique female entrepreneurial challenge. Although some females may willingly enter into entrepreneurial activity when having children as this may provide more work-life flexibility, some may be challenged by time restrictions, especially when children are still young (Noseleit, 2014:550). However, empirical data show that females who decide to become self-employed may in many cases do so to enjoy higher work-life flexibility or to reduce potential work-family conflict (Wilde, Batchelder \& Ellwood, 2010).

DeMartino and Barbato (2003:816) found that fewer differences were observed between males with children and males without children, compared to females with and without children, therefore implying that the responsibility of children among men does not have a large effect on their business motivation and activities. Noseleit (2014:550) opines that clear differences in entrepreneurial motivation among gender, married and unmarried gender groups and groups with and without children exist. A study conducted in the USA that included 2840 MBA alumni returned the following results (Table 1) pertaining to marital status, having children or not and the reason for self-employment. Six motivations were listed that included having career flexibility, being able to create family-friendly policies to assist employees with children, being able to tend to family obligations, forming a co-career with one's spouse, advancing one's career and creating wealth. 
Table 1: Reason for self-employment by gender

\begin{tabular}{lllllll}
\hline \multirow{2}{*}{ Motivation } & \multirow{2}{*}{ Female } & \multirow{2}{*}{ Male } & \multicolumn{2}{c}{ Married with children } & \multicolumn{2}{c}{ Married without children } \\
\cline { 6 - 7 } & & & Female & Male & Female & Male \\
\hline Career flexibility & 85.4 & 50.8 & 96.4 & 55.3 & 68.4 & 48.1 \\
\hline Family-friendly policies & 64.6 & 28.7 & 92.9 & 35.0 & 21.1 & 15.4 \\
\hline Family obligations & 54.1 & 22.8 & 78.6 & 29.3 & 15.8 & 11.8 \\
\hline Co-career with spouse & 58.3 & 21.8 & 71.4 & 22.8 & 36.8 & 21.2 \\
\hline Advancement & 23.4 & 42.7 & 17.9 & 43.6 & 27.8 & 47.1 \\
\hline Wealth creation & 29.1 & 75.9 & 21.4 & 76.5 & 36.8 & 76.9 \\
\hline
\end{tabular}

*This sample included only those who were married and self-employed

Source: $\quad$ DeMartino and Barbato (2003:824)

Although respondents from the sample had similar backgrounds (Alumni from MBA programmes), demographics, as well as timing and age of business, clear differences in motivation between gender and number of dependents, were noted. From Table 1 it is evident that among married females in total, those with and without children choose to be self-employed to ensure a flexible career in order to achieve a work-life balance. Males in all three comparisons indicated that wealth creation was their main motivation for self-employment. These findings correspond to previous findings by Goffee and Scase (1983), Kaplin (1988) and Buttner (1993), however, they contradict findings by Fischer, Reuben and Dyke (1993). Again, these findings may differ in developing countries where some females may be restricted from starting businesses due to other socio-cultural barriers. In light of the aforementioned discussion, the following hypothesis was developed:

H1: There is no significant difference in internal and external motivation, intention to remain in business, intention to grow the business, government support, financial restraints, socio-cultural barriers and attitude towards the business between South African female entrepreneurs who have children and those who do not have children.

\section{METHODOLOGY}

\subsection{Research purpose and design}

Following the main purpose of this study, the underlying philosophical underpinning forms part of the positivist paradigm as it predominantly made use 
of empirical data obtained objectively and interpreted in a statistical manner. This study made use of a descriptive single-sample cross-sectional design approach.

\subsection{Study area and sample}

The target population for this sample included South African female business owners from all nine provinces. Additional criteria included that they owned a majority share in the business and were actively involved in the management aspects of the business. A combination of two non-probability sampling techniques were used in the selection of the sample elements as identified from the target population. First, a purposive sampling technique was utilised as it focuses on characteristics of a population based on the objective of the study, in this case female entrepreneurs owning a business for longer than a year (Crossman, 2017). Second, a convenience sampling technique was employed based on specific participant selection criteria. The decision to utilise this technique was made on the basis that no, or limited, prior knowledge of the precise locations and the names of the individuals from which the sample could be drawn, was available. As the exact population size of female business owners in South Africa is unknown, it was difficult to statistically determine the sample size to present a reflective proportion of the whole population. Avikaran (1994:29) advises that a sample size of between 200 and 500 should be used when undertaking multivariate statistical analysis. A final sample size of 510 female entrepreneurs was obtained and was deemed adequate.

\subsection{Research instrument and procedure}

Data were collected through the use of a self-administered questionnaire. The questionnaire followed a rigorous process of pre-testing and a pilot study before the final study was conducted. The pilot study consisted of a total of 34 female entrepreneurs. As the main study was to be conducted in all nine provinces of South Africa, the pilot study was conducted in one of South Africa's neighbouring countries, Namibia. This was done in an attempt to avoid the possibility that the pilot study respondents may accidentally be included in the main study. The results from the pilot study indicated that the calculated measures of internalconsistency reliability, together with those of convergent and discriminant validity, were deemed acceptable and no changes were made to the questionnaire based on the pilot study results. The final questionnaire was administered through electronic correspondence and trained fieldworkers. Statements and questions included in the measuring instrument pertained general demographic information 
and several constructs directed at obtaining information regarding various entrepreneurial factors. The scaled responses allowed for a selection of between 1 (strongly disagree) to 6 (strongly agree) on a Likert scale and therefore higher means represented a more positive attitude from the respondents based on the specific construct topic.

\subsection{Data analysis}

This analysis employed both descriptive and inferential statistics. In order to address the research hypothesis, statistical analyses were employed and reported on using SPSS 24 for Windows program (SPSS, 2018). Descriptive statistics (means, standard deviations, skewness and kurtosis) of the identified factors (government support, financial constraints, socio-cultural barriers, internal and external motivation, intention to grow, intention to stay in business, attitude towards business) were also computed to describe the data (Table 2). Cronbach alpha coefficients were used to determine the internal consistency of the research instruments. Furthermore, MANOVA and ANOVA analyses were done to determine the significant relationship between dependent variables (the government support, financial constraints, socio-cultural barriers, internal and external motivation, intention to grow, intention to stay in business, attitude towards business) and individual characteristic (fixed factors - female entrepreneurs with and without children) that included women with children and those without children. Firstly, demographic characteristics were analysed for statistical significance using Wilk's Lambda statistics and values on the dependent variables.

\section{RESULTS AND DISCUSSION}

In Table 2 the results of the descriptive statistics and alpha coefficient of the total sample are reported on.

\section{Table 2: Descriptive statistics}

\begin{tabular}{lcccccc}
\hline Factor/variable & Mean & SD & Skewness & Kurtosis & $\boldsymbol{\alpha}$ & $\begin{array}{c}\text { Inter-item } \\
\text { correlation }\end{array}$ \\
\hline Government support & 4.452 & 0.984 & -1.080 & 0.908 & 0.79 & 0.391 \\
\hline Financial constraints & 4.567 & 0.813 & -1.589 & 2.933 & 0.86 & 0.339 \\
\hline Socio-cultural barriers & 4.148 & 1.053 & -0.603 & -0.448 & 0.83 & 0.416 \\
\hline Internal motivation & 5.067 & 0.509 & -0.660 & 2.422 & 0.75 & 0.179 \\
\hline External motivation & 4.867 & 0.724 & -1.054 & 1.865 & 0.73 & 0.260 \\
\hline Intention to grow & 5.170 & 0.815 & -1.764 & 3.772 & 0.77 & 0.524 \\
\hline Intention to stay & 5.071 & 0.757 & -1.809 & 5.189 & 0.73 & 0.372 \\
\hline Attitude towards business & 4.959 & 0.603 & -0.970 & 2.635 & 0.82 & 0.248 \\
\hline
\end{tabular}


Table 2 shows acceptable Cronbach alpha coefficients varying from 0.73 to 0.86 (Nunnally \& Bernstein, 1994). Concerning construct validity, the average interitem correlation values fall within Clark and Watson's (1995:316) recommended levels of 0.15 to 0.50 , with the intention to growing a business being marginally higher. As such, it was reasonable to assume convergent and discriminant validity.

Multiple Analysis of Variance (MANOVA) and Analysis of Variances (ANOVA) were used to test Hypothesis (HI): there is no significant difference in internal and external motivation, intention to remain in business, intention to grow the business, government support, financial constraints, socio-cultural barriers and attitude towards the business between South African female entrepreneurs who have children and those who do not have children.

\section{Table 3: MANOVA results for differences between variables and females' children status}

\begin{tabular}{llllll}
\hline Item & Value & F & Df & $\boldsymbol{p}$ & $\begin{array}{l}\text { Partial Eta } \\
\text { Squared }\left(\eta^{2}\right)\end{array}$ \\
\hline $\begin{array}{l}\text { Female entrepreneurs with or } \\
\text { without children }\end{array}$ & 0.93 & 3.19 & 11.00 & $0.00^{*}$ & 0.07 \\
\hline$* \mathrm{p}<0.05=$ significant & & & &
\end{tabular}

Table 3 clearly indicates that from a South African perspective a significant difference in internal and external motivation, intention to remain in business, intention to grow the business, government support, financial restraints, sociocultural barriers and attitude towards the business between South African female entrepreneurs who have children and those who do not have children was experienced. Veena and Nagaraja (2013:139) opine that male and female entrepreneur's impact of marital status and having children differs significantly. Males tend to have less conflicting demands when it comes to family responsibility. In addition, the DTI (2005:8) also identified family responsibility as a potential unique female entrepreneur challenge.

The next phase involved identifying where the differences between groups existed because significant effects were identified in the MANOVA analysis (Table 3). ANOVA was used to determine this (George \& Mallery, 2003). Table 4 presents the results from the ANOVA test. 
Table 4: ANOVA results for differences between variables and children status groups

\begin{tabular}{lllll}
\hline Factor/variable & Children & No children & $\boldsymbol{p}$ & $\boldsymbol{\eta}^{\mathbf{2}}$ \\
\hline Government support & 4.62 & 4.32 & $0.00^{*}$ & 0.02 \\
\hline Financial constraints & 4.68 & 4.47 & $0.00^{*}$ & 0.02 \\
\hline Socio-cultural barriers & 4.33 & 3.99 & $0.00^{*}$ & 0.03 \\
\hline Internal motivation & 5.05 & 5.08 & 0.58 & 0.00 \\
\hline External motivation & 4.89 & 4.85 & 0.52 & 0.00 \\
\hline Intention to grow & 5.17 & 5.17 & 0.97 & 0.00 \\
\hline Intention to stay & 5.07 & 5.07 & 0.95 & 0.00 \\
\hline Attitude towards business & 4.92 & 4.99 & 0.15 & 0.00 \\
\hline$* \mathrm{p}<0.05=$ significant & & & & \\
$\eta 2>0.25=$ large effect & & & &
\end{tabular}

From a South African perspective, the set hypothesis (HI) is rejected as significant differences were found between entrepreneurial females with and without children and government support, financial constraints and socio-cultural barriers. Female entrepreneurs with children experience more financial constraints and social barriers than female entrepreneurs without children and also experience the level of government support provided to them differently. Shelton (2006:289) reasons that work-family conflict, such as raising children, is correlated positively to business demands and family role demands. Business demands involve for example hours worked and entrepreneurial aspirations. Family role demands depend on, for example, the ages and number of children and the magnitude of family support. Female entrepreneurs may choose to limit the scope of their businesses in order to reduce potential work-family conflict. The findings also suggest that female entrepreneurs, regardless of their child status are motivated to stay in and grow the business. Their attitude towards the business also remains positive in both situations.

\section{CONCLUSION AND RECOMMENDATIONS}

The significance of this study can be divided into two parts, first, a theoretical and practical influence for female entrepreneurs with or without children. Theoretically, the background of female entrepreneurs' theory and content from an international and South African perspective were discussed. The second part of the study, empirically indicated that the influence of government support, financial constraints and social-cultural barriers play a role for female entrepreneurs with children. In addition, findings indicate that female 
entrepreneurs are resilient and that even with the added challenge of child-caring responsibilities, they still intend to stay in and grow their businesses and that they have a positive attitude towards their businesses. The presence of children also does not have a significant statistical effect in their overall business motivation. These findings motivate further studies focusing on the relationship between the experience of female entrepreneurs and social context in which they are functioning in and to identify the reasons why female entrepreneurs experience a difference regarding government support, financial constraints and social-cultural barriers. Recommendations emanating from the findings of this study may include the promotion of female entrepreneurial networks and associations, greater media attention on the importance of female entrepreneurship, better implementation of policies and awareness thereof, greater motivation and assistance for business growth, exposing females to the business environment from a young age, greater representation of females in the business world, enhanced finance opportunities and developing a greater understanding of the female entrepreneurship phenomenon.

There are limitations and methodology aspects that affected the results presented in this study. The self-reported procedure utilised can be improved by more controlled application of the questionnaire and could result in minimising the bias of the findings. Time impact on the perception of female entrepreneurs with or without children may differ over time and the impact may only be noticeable at a later stage.

\section{REFERENCES}

Ajzen, I. (1991). The theory of planned behaviour. Organizational Behavior and Human Decision Processes, 50(2),179-211.

Ambrish, D.R. (2014). Entrepreneurship development: An approach to economic empowerment of female. International Journal of Multidisciplinary Approach and Studies, 1(6), 224-232.

Asian Development Bank. (2007). Technical Assistance Report. Promoting rural women's entrepreneurship in transition economies. Asian Development Bank.

Athayde, R. (2012). The impact of enterprise education on attitudes to enterprise in young people: An evaluation study. Education and Training, 54(8/9), 709-725.

Avikaran, N.K. (1994). Developing an instrument to measure customer service quality in branch banking. International Journal of Bank Marketing, 12(6), 10-18. 
Bobby-Evans, A. (2015). Apartheid Legislation in South Africa. http://africanhistory. about.com/library/bl/blsalaws.htm. Accessed: 2015/09/03.

Buttner, E.H. \& Rosen, B. (1988). Bank loan officers' perceptions of the characteristics of men, women, and successful entrepreneurs. Journal of Business Venturing, 3(3), 249-258.

Buttner, E.H. (1993). Female entrepreneurs: How far have they come? Women in business. Business Horizons, 36(2), 59-68.

Clark, L.A. \& Watson, D. (1995). Constructing validity: Basic issues in objective scale development. Psychological Assessment, 7(3), 309-319.

Crossman, A. (2017). Understanding purposive sampling. An overview of the methods and its applications. www.thoughtco.com. Accessed: 2017/09/23.

Delmar, F. \& Wiklund, J. (2008). The effect of small business managers' growth motivation on firm growth: A longitudinal study. Entrepreneurship Theory and Practice, 32(3), 437-457.

DeMartino, R. \& Barbato, R. (2003). Difference between women and men. Journal of Business Venturing, 18(2003), 815-832.

DTI see Republic of South Africa. Department of Trade and Industry Fischer, E., Reuben, R.A. \& Dyke, L.S. (1993). A theoretical overview and extension of research on sex, gender, and entrepreneurship. Journal of Business Venturing, 8(2), 151-168.

GEM Consortium. (2017). Global Entrepreneurship Monitor: Key indicators Adult population survey measures. http://www.gemconsortium.org/data/keyindicators. Accessed: 2017/05/24.

George, D., \& Mallery, P. (2003). SPSS for Windows step by step: A simple guide and reference 11.0 update ( $4^{\text {th }}$ ed.). Boston, MA: Allyn \& Bacon.

Gicheva, D. \& Link, A.N. (2015). The gender gap in federal and private support for entrepreneurship. Small Business Economics, 45(4), 729-733.

Goffee, R. \& Scase, R. (1983). Business ownership and women's subordination: A preliminary study of female proprietors. The Sociological Review, 31(4), 625648. 
Herrington, M., Kew, J. \& Kew, P. (2010). Global Entrepreneurship Monitor. University of Cape Town. Cape Town: South Africa.

Herrington, M., Kew, J. \& Kew, P. (2015). 2014 GEM South Africa report: South Africa: The crossroads - a goldmine or a time bomb? University of Cape Town Centre for Innovation and Entrepreneurship. Cape Town: South Africa.

International Labour Organization (ILO). (2014). Female's entrepreneurship development: Encouraging female entrepreneurs for jobs and development. http://www.ilo.org/wcmsp5/groups/public/---ed_emp/---emp_ent/--ifp_seed/documents/publication/wcms_175471.pdf. Accessed: 2015/07/29.

Jayachandran, S. (2014). The roots of gender inequality in developing countries. http://faculty.wcas.northwestern.edu/ sjv340/roots_of_gender_inequality.pdf. Accessed: 2015/09/02.

Kaplin, E. (1988). Women entrepreneurs: Constructing a framework to examine venture success and business failure. Frontiers of Entrepreneurship Research, (1988), 625-637.

Kim, M.S. \& Hunter, J.E. (1993). Relationships among attitudes, behavioral intentions, and behavior: A meta-analysis of past research, part 2. Communication research, 20(3), 331-364.

Kim, S.M., \& Sherraden, M. (2014). The impact of gender and social networks on microenterprise business performance. Journal of Sociology \& Social Welfare, 41, 49-69.

Knight, W.E. \& Leimer, C.L. (2010). Will IR staff stick? An exploration of institutional researchers' intention to remain in or leave their jobs. Research in Higher Education, 51(2), 109-131.

Kot, S., Meyer, N., \& Broniszewska, A. (2016). A cross-country comparison of the characteristics of Polish and South African women entrepreneurs. Economics and Sociology, 9(4), 207-221. DOI: 10.14254/2071-789X.2016/9-4/13.

Makina, D., Fanta, A.B., Mutsonziwa, K., Khumalo, J. \& Maposa, O. (2015). Financial access and SME size in South Africa. Occasional Paper (001-2015). University of South Africa.

Maziku, P., Majenga, A. \& Mashenene, G.R (2014). The effects of socio-cultural factors on the performance of women small and medium enterprises in Tanzania. Journal of Economics and Sustainable Development, 5(21), 51-63. 
Morrison, K.A. (1997). How franchise job satisfaction and personality affects performance, organizational commitment, franchisor relations, and intention to remain. Journal of Small Business Management, 35(3), 39-67.

Noseleit, F. (2014). Female self-employment and children. Small Business Economies, 43, 549-569. DOI 10.1007/s11187-014-9570-8.

Nunnally, J.C., \& Bernstein, I.H. (1994). Psychometric Theory. New York: McGraw-Hill.

Onyishi, I.E. \& Agbo, A.A. (2010). Psychological empowerment and development of entrepreneurship among women: Implications for sustainable economic development in Nigeria. Gender and Behaviour, 8(2), 3048-3068.

Republic of South Africa. Department of Trade and Industry (DTI). (2005). South African female entrepreneurs. A burgeoning force in our economy: A special report 2005. Pretoria: Government Printer.

SAHO see South Africa History Online

Sailus, C. (2015). Feminism in the $19^{\text {th }}$ century: Female's rights, roles, and limits. $\mathrm{http}$ //study.com/academy/lesson/feminism-in-the-19th-century-females-rightsroles-and-limits.html. Accessed: 2015/09/02.

Shelton, L.M. (2006). Female entrepreneurs, work-family conflict, and venture performance: New insights into the work-family interface. Journal of Small Business Management, 44(2), 285-297.

Sivvam, M. (2012). Female entrepreneurship: An Indian perspective. Saarbrücken, Germany: LAP Lambert.

South Africa History Online (SAHO). (1994). South African first democratic elections. http://www.sahistory.org.za/dated-event/south-africas-first-democraticelections. Accessed: 2016/01/21.

South African History Online (SAHO). (2011). Pass laws in South Africa 18001994. http://www.sahistory.org.za/south-africa-1806-1899/pass-laws-south-africa1800-1994. Accessed: 2015/09/03.

SPSS - IBM Corporation. (2018). IBM SPSS Statistics for Windows (Version 25.0). Armonk, NY: IBM Corporation.

United Nations (UN). (2008). Female 2000 and beyond: Rural female in a changing world: Opportunities and challenges. Geneva: United Nations Publishers. 
Veena, M. \& Nagaraja, N. (2013). Comparison of male and female entrepreneurs: An empirical study. International Journal of Engineering and Management Research, 3(6), 138-143.

Verheul, I. \& Thurik, R. (2001). Start-up capital: Does gender matter? Small Business Economics, 16(4), 329-346.

Walker, E. \& Brown, A. (2004). What success factors are important to small business owners? International Small Business Journal, 22(6), 577-594.

Wiklund, J., Davidsson, P. \& Delmar, F. (2003). What do they think and feel about growth? An expectancy- value approach to small business managers' attitudes toward growth. Entrepreneurship Theory and Practice, 27(3), 247-270.

Wilde, E.T., Batchelder, L. \& Ellwood, D.T. (2010). The mommy track divides: The impact of childbearing on wages of women of differing skills levels. NBER Working Paper, 16582. 